\title{
The eclipse phase of vaccinia virus growing in chick embryo cell monolayers and some technical procedures which affect its demonstration
}

\author{
By R. POSTLETHWAITE AND H. B. MAITLAND \\ Bacteriology Department, University of Manchester
}

(Received 26 November 1959)

\section{INTRODUCTION}

It has been possible with a number of viruses to obtain evidence of an eclipse phase by showing that in the early stages of a culture the amount of infective virus decreases and that the titre of cells which will ultimately produce virus (infective centres) is greater than the titre of virus released by disintegrating the cells.

With vaccinia the evidence has not been uniform or entirely satisfactory. Reports in the literature present somewhat different pictures of the changes in infectivity of vaccinia virus when it is grown either in vivo or in vitro. Rapid fall in infectivity of inoculated virus (Briody \& Stannard, 1951; Forsyth, Cook \& Irons, 1954) contrasts with gradual loss of infective virus (Crawford \& Sanders, 1952; Anderson, 1954) just as a complete disappearance of infectivity (Forsyth et al. 1954; Ryden \& Randall, 1957) is at variance with a regularly found proportion of residual infective virus (Crawford \& Sanders, 1952; Anderson, 1954; Maitland \& Tobin, 1956; Maitland \& Postlethwaite, 1959) before new mature virus appears. Some have found that the infectivity increased steadily with time, but Briody \& Stannard (1951) and Ryden \& Randall (1957) indicated a step-wise increase. Anderson (1954) demonstrated the absence of infective virus in pieces of chorioallantoic membrane and the production of virus by similar pieces when they were transplanted, thus indicating an eclipse phase. The validity of the experiments depended, however, on the certainty of detecting small amounts of virus in disintegrated tissue. No one has reported finding a difference between the titre of a suspension of whole cells made from a culture and similar disintegrated cells.

Maitland \& Postlethwaite (1959) with cultures in HeLa cells, found a gradual loss of infective virus, during incubation for 8-10 hr., amounting to about $70 \%$ of the virus which had been adsorbed from the inoculum and not neutralized by antiserum. This loss appeared to be due to the action of the cells and could have been an eclipse phase but there was no supporting evidence for this interpretation. A suspension of cells made from a culture during the period of low infectivity, when an eclipse phase would be expected, was titrated on eggs and compared with disintegrated cells. They had about the same titre.

The present report concerns further attempts to demonstrate an eclipse phase in chick embryo cell cultures. During the course of this work it was found that ultrasonic treatment of the inoculum had a marked effect on the results obtained; other points in technique are discussed. 


\section{MATERIAL AND ME'THODS \\ Virus}

An elementary body suspension was prepared from infected rabbit skin after the method of Hoagland, Smadel \& Rivers (1940) using as inoculum a rabbit dermal passaged virus originally derived from the Lister Institute strain of vaccinia used for preparing smallpox vaccine. The high-speed centrifugations were carried out in a Spinco ultracentrifuge and the final material was stored in $0 \cdot 004 \mathrm{M}$ Mcllvaine's buffer, $\mathrm{pH} 7 \cdot 3$, at $-20^{\circ} \mathrm{C}$.

\section{Chick embryo monolayers}

Confluent monolayers of chick embryo cells were prepared in $50 \mathrm{~mm}$. Petri dishes, using trypsinized cell suspensions from 11-day-old minced chick embryos, discarding head, limbs and viscera, in a medium of $20 \%$ calf serum and $0.25 \%$ lactalbumin hydrolysate in Hanks's balanced salt solution. Each dish received about $8 \times 10^{6}$ cells. The dishes were incubated in $5 \% \mathrm{CO}_{2}$ in air at $37^{\circ} \mathrm{C}$. for $48 \mathrm{hr}$., when the medium was removed and replaced with $3 \mathrm{ml}$. Eagle's medium for $1 \mathrm{hr}$. This was removed before inoculation.

\section{Saline solutions and virus diluents}

Earle's salt solution was used to wash monolayers and as a virus diluent with or without addition of $0.1 \%$ gelatin.

In all media penicillin was incorporated at a final concentration of $100 \mathrm{units} / \mathrm{ml}$. and streptomycin at $100 \mu \mathrm{g} / \mathrm{mI}$.

\section{Ultrasonic treatment of virus and infected cells}

Virus, infected monolayers or suspensions of cells, usually in a volume of 2 or $4 \mathrm{ml}$., in $50 \mathrm{~mm}$. Petri dishes, were placed under the 1:1 ratio chromium plated stub of a Mullard $50 \mathrm{~W}$. ultrasonic drill so that the stub just touched the surface of the liquid in the dish. The machine was switched on and the dish moved continuously to ensure that the whole area would come directly under the vibrating stub.

\section{Titration of virus}

(a) Pock counts on the chorio-allantoic membrane. $0.05 \mathrm{ml}$. of material for assay was placed on the dropped chorio-allantoic membrane of seven or eight 13-day-old embryos per tenfold dilution. Unweighted pock counts were made after incubation for 2 days at $36 \cdot 5^{\circ} \mathrm{C}$.

(b) Plaque counts. $0.5 \mathrm{ml}$. of material for assay was placed on each of three chick embryo monolayers in $50 \mathrm{~mm}$. Petri dishes followed by $2 \mathrm{ml}$. of Eagle's medium. After incubation for $36 \mathrm{hr}$. the medium was removed and carbolfuchsin (Ziehl-Neelsen's strain for tubercle bacilli) applied for 5-6 sec. This was washed off with water and the dishes drained and allowed to dry. Plaques were counted either before or after drying as described by Postlethwaite (1959). 


\section{Antiserum}

Hyperimmune antisera were prepared in rabbits by initial intradermal inoculation followed by a course of intravenous injections of the elementary body suspensions described under 'Virus'. After inactivation at $56^{\circ} \mathrm{C}$. for $30 \mathrm{~min}$. the antisera were stored at $-20^{\circ} \mathrm{C}$.

\section{Trypsin}

$0 \cdot 25 \%$ Difco trypsin in phosphate-buffered saline without calcium or magnesium.

\section{Ethylenediaminetetra-acetic acid (EDTA)}

$0.02 \%$ in phosphate-buffered saline without calcium or magnesium.

\section{EXPERIMENTAL}

I. Changes in infectivity (growth curve) of vaccinia virus in chick embryo cell monolayers infected with ultrasonically treated inoculum

Virus, diluted in Earle's solution plus gelatin, to be used as inoculum, was treated for $1 \mathrm{~min}$. ultrasonically and diluted further at least 30-fold. Each monolayer received $2 \mathrm{ml}$. of inoculum which was removed after $5 \mathrm{~min}$. at $21^{\circ} \mathrm{C}$. The cells were then washed three times with $2 \mathrm{ml}$. of Earle's saline and 2 or $4 \mathrm{ml}$. of Eagle's medium were added. Cultures were incubated in $5 \% \mathrm{CO}_{2}$ in air at $37^{\circ} \mathrm{C}$.

The amount of adsorbed virus was ascertained by incubating some dishes for $36 \mathrm{hr}$. and making plaque counts. In most experiments the inoculum was so strong that a 1/100 dilution of it was used for this purpose and the plaque count $\times 100$ taken as the amount adsorbed in the experimental dishes. This procedure was possible because for a given period of adsorption a linear relationship was shown between concentration of inoculum and the amount of virus adsorbed.

By titrating the inoculum in any experiment on the chorio-allantoic membrane and on monolayers (see Materials and Methods) the pock:plaque ratio was obtained and from this ratio the plaque count of adsorbed virus could be converted to an equivalent pock-count value.

Changes in virus content of cultures during incubation were determined by disintegrating the cells with ultrasonic treatment for $1 \mathrm{~min}$. pooling the contents of two dishes, and titrating this by plaque and pock counts after suitable dilution (see $\S \mathrm{VI}$ ).

The results of two representative experiments are shown in Table 1. Although the ratio of pock to plaque counts was about $2: 1$ each method of titration led to similar conclusions.

The first titration of disintegrated cells, made as soon as medium was added, 10 min. after first contact between inoculum and monolayer, showed that within this relatively short time, $80-90 \%$ of adsorbed virus appeared to have lost its infectivity as only $10-20 \%$ was recovered. A similar experiment, which avoided titrating diluted inoculum to find the amount of adsorbed virus, confirmed the rapid loss of infectivity. Four inocula, in successive twofold dilutions, were used, so that one of them would be found to give suitable counts for evaluating both the 
adsorbed virus and the virus content of disintegrated monolayers. The results are shown in Table 2. The quantity of virus adsorbed was reasonably proportionate to strength of inoculum. Within $11 \mathrm{~min}$. of first contact of virus with monolayer between 35 and $70 \%$ of the adsorbed virus had disappeared. In other similar experiments $(\S \mathrm{VI} c$ ) the loss was $40-80 \%$.

Table 1. Changes in titre of virus during incubation of chick embryo cell monolayers infected with ultrasonically treated inoculum

\begin{tabular}{|c|c|c|c|c|}
\hline \multirow[b]{2}{*}{$\begin{array}{l}\text { Hours after } \\
\text { adding } \\
\text { inoculum }\end{array}$} & \multicolumn{2}{|c|}{ Plaque counts } & \multicolumn{2}{|c|}{ Pock counts } \\
\hline & $\begin{array}{c}\% \text { of } \\
\text { adsorbed } \\
\text { virus }\end{array}$ & $\begin{array}{c}\% \text { of } \\
\text { count at } \\
10 \text { min. }\end{array}$ & $\begin{array}{c}\% \text { of } \\
\text { adsorbed } \\
\text { virus }\end{array}$ & $\begin{array}{c}\% \text { of } \\
\text { count at } \\
10 \text { min. }\end{array}$ \\
\hline & & Expt. 1 & & \\
\hline & (1) & (2) & (3) & (4) \\
\hline 0.10 & 11 & 100 & 18 & 100 \\
\hline 0.20 & 12 & 114 & 13 & 73 \\
\hline 0.45 & 10.5 & 100 & 15 & 85 \\
\hline 0.55 & 13 & 119 & 13 & 75 \\
\hline 1.25 & 12 & 116 & 19 & 104 \\
\hline 2.30 & 11 & 103 & 10 & 55 \\
\hline 3.40 & 7 & 69 & $8 \cdot 5$ & 47 \\
\hline 4.40 & 5 & 50 & 6 & 35 \\
\hline 6.30 & - & - & 8 & 44 \\
\hline 7.10 & $\cdots$ & - & 12 & 65 \\
\hline 8.10 & 一 & - & 22 & 122 \\
\hline 9.15 & - & - & 32 & 178 \\
\hline 10.15 & 69 & 647 & 55 & 307 \\
\hline 24.00 & - & - & $46 \times 10^{3}$ & $2 \cdot 6 \times 10^{5}$ \\
\hline
\end{tabular}

Expt. 2

$\begin{array}{rrrcc}0.10 & 18 & 100 & 20 & 100 \\ 0.35 & 17 & 93 & 18 & 89 \\ 1.10 & 13 & 71 & - & - \\ 2.35 & 8 & 42 & - & - \\ 3.45 & 7 & 37 & 7 & 33 \\ 5.15 & 3 & 16 & 4 & 20 \\ 7.00 & 5 & 26 & 15 & 72 \\ 8.50 & 55 & 300 & 56 & 276 \\ 10.30 & 183 & 1760 & 136 & 669 \\ 24.30 & 38 \times 10^{4} & 2 \times 10^{6} & 13 \times 10^{4} & 6.4 \times 10^{5}\end{array}$

Counts per dish were as follows: (1) 33,$800 ;(2) 3600 ;(3) 62,000 ;(4) 11,000 ;(5) 20,600$; (6) 3800 ; (7) 45,700 ; (8) 9300 .

During the incubation of cultures there was a further loss of infectivity amounting to $60-70 \%$ of the virus found at $10 \mathrm{~min}$. This is shown in Table 1, taking as the base line the titre of disintegrated monolayers $10 \mathrm{~min}$. after first contact with virus. After the initial rapid loss the rate of further loss was slower, the lowest point being reached in $4-6 \mathrm{hr}$. The downward trend was reversed by production of new virus, indicated by a rising titre at $7-8 \mathrm{hr}$. 
Some points need to be made regarding the rapid loss of an apparently large amount of adsorbed virus. In the first place it occurred with ultrasonically treated inoculum; it was not demonstrable with similar but untreated inoculum. The nature of the alteration in virus which made this rapid loss apparent is not known, but it may be dispersion of clumps (as discussed in $\S I I I$ ). In the second place the amount of loss has to be considered in relation to the efficiency of recovering virus from infected monolayers by disintegrating them. The question arises, how much of this loss is due to failure to release virus from the cells or to detect it by titration? The efficiency of ultrasonic treatment in releasing virus is satisfactory compared with other methods (cf. $\S \mathrm{VI}$ ) but there is no certainty that absolutely all the virus is recovered. Treatment of an elementary body suspension with trypsin increased the titre two- to fourfold and it might have a similar effect on disintegrated cells. The conclusion, therefore, is that although some virus lost its infectivity within a few minutes after it was adsorbed to a monolayer of chick embryo cells the amount was difficult to assess but was probably less than the actual experimental results. The apparent loss, considering all the results, was up to $80 \%$; the significant loss may be about $40-50 \%$.

Table 2. Rapid loss of virus in chick embryo monolayers infected by contact for 5 min with ultrasonically treated inoculum

$\begin{array}{lccc}\text { A. Amount of } & \begin{array}{c}\text { B. Virus recovered } \\ \text { from monolayers } \\ \text { disintegrated 11 min. } \\ \text { after the first } \\ \text { adsorbed } \\ \text { vilution of } \\ \text { inoculum }\end{array} & \begin{array}{c}\text { Pirus } \\ \text { contact with virus }\end{array} & \begin{array}{c}\text { B as } \% \\ \text { of A }\end{array} \\ \text { Undiluted } & 764 & 253^{*} & 33 \\ 1 \text { in } 2 & 406 & 120 & 30 \\ 1 \text { in } 4 & 181 & 93 & 51 \\ 1 \text { in } 8 & 84 & 53 & 63\end{array}$

* Calculated from plaque counts of 6,5 8. The disintegrated cells were diluted 1 in 10 before inoculation.

Presumably the rapid loss of infectivity is the beginning of the process that continues more gradually for several hours. Loss of infectivity in itself does not necessarily mean that the elementary body has broken up prior to replication of new virus material. Evidence that 'eclipse' has occurred in cultures a few hours old based on absence of infective virus in cells that ultimately produced it is presented in §II. Similar evidence has not yet been sought, as an explanation of the rapid loss, a few minutes after first contact between monolayers and inoculum. This aspect requires further investigation. The rapid loss of infectivity may possibly be regarded as the beginning of cell infection. The escape of adsorbed virus from the neutralizing effect of antiserum, which probably indicates the beginning of infection, also has a rapid initial phase. The initial rapidity of the process and 
gradual decrease in rate may indicate differences in cell activity rather than differences in individual elementary bodies but no evidence on these points is presented.

\section{Titration of intact and disintegrated cell suspensions from cultures infected with ultrasonically treated inoculum}

The cultures were prepared as described in the preceding section.

Experiment 1. After incubation for $5 \mathrm{hr}$. the medium was removed and the monolayer washed twice with phosphate-buffered saline without calcium or magnesium. The cells were dispersed with EDTA and the contents of two dishes pooled. Part of the cell suspension was used to titrate the number of infected cells by pock and by plaque counts; the remainder was disintegrated ultrasonically and titrated similarly The plaque counts per dish were 6672 for whole cells and 224 for disintegrated cells, a ratio of about $30: 1$; the pock counts were respectively 6720 and 1184 , a ratio of $5 \cdot 7: 1$.

Table 3. Titration of whole and disintegrated cell suspensions prepared from chick embryo monolayers infected with ultrasonically treated inoculum at intervals after incubation

\begin{tabular}{|c|c|c|c|c|}
\hline \multirow[b]{2}{*}{$\begin{array}{l}\text { Hours of } \\
\text { incubation }\end{array}$} & \multicolumn{2}{|c|}{ Plaque counts per dish } & \multicolumn{2}{|c|}{ Pock counts per dish } \\
\hline & Whole cells & $\begin{array}{c}\text { Disintegrated } \\
\text { cells }\end{array}$ & Whole cells & $\begin{array}{c}\text { Disintegrated } \\
\text { cells }\end{array}$ \\
\hline 1.00 & 4,000 & 850 & 7,500 & 5,100 \\
\hline 3.00 & 6,400 & 780 & 8,300 & 1,300 \\
\hline 4.45 & 14,000 & 660 & 13,000 & 800 \\
\hline 5.30 & 11,000 & 700 & 10,000 & 1,200 \\
\hline 8.30 & 28,000 & 4,400 & 23,000 & 8,600 \\
\hline 10.30 & 118,000 & 28,700 & 78,000 & 30.000 \\
\hline 25.00 & $7 \cdot 3 \times 10^{6}$ & $11 \cdot 6 \times 10^{6}$ & $11.4 \times 10^{6}$ & $39 \times 10^{6}$ \\
\hline
\end{tabular}

Experiment 2. In another comparable experiment infected monolayers, after incubation for different periods, were dispersed by trypsin, washed twice by centrifuging in Earle's saline at 1500 r.p.m. for 5 min. and suspended in Earle's saline plus gelatin before titrating both whole and disintegrated cells by pock and plaque counts. The results are shown in Table 3.

After about $5 \mathrm{hr}$. of incubation, when the amount of virus in cultures had fallen to a low level, the titre of cells capable of ultimately producing virus was considerably higher than the titre of virus obtained by disintegrating them, the ratio being about 15:1. The low titre of virus in the disintegrated cells was not due to destruction of virus by the ultrasonic treatment used to break them up (see $\S$ VII). The loss of infectivity determined by titrating disintegrated cells cannot be estimated precisely as it may be affected by the efficiency of release of virus from the cells, the dilution of the disintegrated cells used for titration ( $\S \mathrm{VI})$ and possibly other uncontrolled factors. Although the ratio of 15:1 is not a strikingly large one it can be interpreted as indicating that cells in the process of producing 
new virus go through a phase when infective virus cannot be demonstrated, the so-called 'eclipse phase'. This result is similar to and amplifies that of Expt. 1.

The number of cells which ultimately produced virus increased steadily during the first 5-6 hr. of incubation while the titre of virus from the disintegrated cells was falling. This suggests that infection of cells and eclipse of virus continued for at least 5-6 hr. after adsorption. There was possibly considerable asynchrony between individual cells during this time. From about $8 \mathrm{hr}$. on, new virus was being produced, shown by rise in titre of virus from disintegrated cells. The increase in number of infected cells during this period suggests that some new virus escaped soon after it was formed and spread to other cells.

\section{POSSIBLE FALLACIES INHERENT IN EXPERIMENTAL PROCEDURES}

Although the main findings from these experiments are clear, some technical matters require consideration as they may influence the outcome of experiments on interaction between vaccinia and cells in culture.

\section{The effect of treating the inoculum ultrasonically on the subsequent interaction between virus and cells}

For convenience, the term 'standard inoculum' will be used to refer to the elementary body suspension described under 'virus' and 'US inoculum' to denote that it has been treated ultrasonically for $1 \mathrm{~min}$. These two inocula behaved differently when infecting monolayers and growing in them. The differences may be indicated by referring to growth curves. With standard inoculum and chick embryo cell monolayers, a rapid loss of adsorbed virus could not be detected and only about $10-15 \%$ disappeared in $6-8 \mathrm{hr}$. before a rise in titre began (Table 4). A large part of the adsorbed virus was not in an infecting relationship with the cells; it was neutralizable by antiserum and it may have obscured the detection of virus that did become non-infective. If the excess of adsorbed virus was eliminated by neutralization with antiserum (for $30 \mathrm{~min}$.) and the titre of disintegrated cells at the beginning of incubation taken as the base line, a fall in titre of about $70 \%$ was found (Table 4 ). This fall was gradual and reached its lowest point in about $8 \mathrm{hr}$. A rise in titre due to formation of new virus began in 10-11 hr.

Similar results were obtained with HeLa cells (Maitland \& Postlethwaite, 1959).

With US inoculum the loss of infectivity of a considerable proportion of adsorbed virus within $10 \mathrm{~min}$. and a further loss of about $70 \%$ of the virus present at that time has already been noted (§I). Thus, compared with standard inoculum, a much greater proportion of virus adsorbed from US inoculum became noninfective, the rate at which this occurred was faster, the rise in titre due to production of new virus began sooner (6-8 hr. instead of 10-12 hr.) and the yield at $24 \mathrm{hr}$. was much higher. In general terms, virus units in U.S. inoculum appeared to be more uniformly capable of infecting cells and going into an eclipse phase and of causing a more rapid production and greater yield, per culture, of new infective virus. Why this should be so is not known. Further studies on elementary body 
suspension before and after ultrasonic treatment, particularly with regard to physical and chemical changes are needed. The titre is increased several times by ultrasonic treatment (Maitland \& Postlethwaite, 1959 and $\S$ VII) and the simplest explanation would be that clumps of virus were dispersed by the treatment. This may be the case but attempts to get convincing evidence of it from electron microscopy or dark ground illumination were not successful and even if it occurs it may or may not explain fully the differences in infectivity and growth.

Table 4. Changes in infectivity during incubation of chick embryo cell monolayers infected with virus NOT treated ultrasonically (standard inoculum)

\begin{tabular}{|c|c|c|}
\hline \multirow[b]{2}{*}{$\begin{array}{l}\text { Hours of } \\
\text { incubation }\end{array}$} & \multicolumn{2}{|c|}{$\begin{array}{l}\text { Plaque counts (mean of three } \\
\text { experiments) as percentage of } \\
\text { titre of disintegrated mono- } \\
\text { layers before incubation }\end{array}$} \\
\hline & $\begin{array}{l}\text { Cultures } \\
\text { incubated } \\
\text { with all the } \\
\text { adsorbed } \\
\text { virus }\end{array}$ & $\begin{array}{c}\text { Cultures } \\
\text { incubated } \\
\text { with } \\
\text { unneutralized } \\
\text { virus }\end{array}$ \\
\hline 0 & $100^{*}$ & $100 \dagger$ \\
\hline 1 & 99 & 67 \\
\hline 2 & 111 & 80 \\
\hline 3 & 125 & 45 \\
\hline 4 & 88 & 43 \\
\hline 5 & 86 & 48 \\
\hline 6 & 116 & 48 \\
\hline 7 & 97 & 44 \\
\hline 8 & 94 & 32 \\
\hline 9 & 215 & 66 \\
\hline 10 & 183 & 41 \\
\hline 11 & 340 & 122 \\
\hline 12 & 149 & - \\
\hline 13 & - & - \\
\hline 24 & 42,000 & 16,000 \\
\hline
\end{tabular}

\section{Comparison of HeLa cell and chick embryo cell monolayers}

There is an a priori assumption that the mechanism of multiplication of vaccinia in these two systems would be similar. They have not been compared directly with regard to susceptibility to infection or amount of virus produced. Both will produce plaques. The growth curves in the two systems, using standard inoculum were similar. Attempts to demonstrate an eclipse phase by detecting a difference in titre of intact and disintegrated cells from HeLa cell cultures, infected with standard inoculum, were, however, unsuccessful (Maitland \& Postlethwaite, 1959) and differed from the results reported here with chick embryo monolayers and US inoculum. This, however, may be attributable to the standard inoculum used with HeLa cells rather than to the cells; standard inoculum in chick embryo cells was likewise unsuccessful. Possibly an eclipse phase could be demonstrated similarly 
in HeLa cells if US inoculum were used. It may be, too, that HeLa cells, dispersed from infected monolayers by EDTA or trypsin, are less capable than chick embryo cells of surviving, when transplanted for titration to chorio-allantoic membrane or a monolayer, maintaining a state which enables them to produce new mature virus.

\section{The release of virus by cells from infected monolayers treated by trypsin or $E D T A$}

The preparation of cell suspensions from infected monolayers of HeLa cells by the application of trypsin or EDTA has shown that this treatment causes the cells to shed virus which they would not release spontaneously into the medium or which would not be removed from the monolayers by washing.

Standard inoculum was applied to monolayers for $1 \mathrm{~min}$. and removed followed by three washes with Earle's saline. Antiserum was then applied for $1 \mathrm{~min}$. and removed followed by three more washes. The antiserum eliminated about 70$75 \%$ of the virus attached to cells, so that what remained was both firmly bound and protected from antiserum. In other experiments with similar results antiserum was applied for as long as $2 \mathrm{hr}$. which neutralized over $90 \%$ of the adsorbed virus. Medium was then added.

Table 5. Release of virus by trypsin from infected chick embryo cell monolayers

\begin{tabular}{|c|c|c|c|c|}
\hline \multirow[b]{2}{*}{$\begin{array}{c}\text { Hours of } \\
\text { incubation }\end{array}$} & \multicolumn{4}{|c|}{ Pocks per dish } \\
\hline & $\begin{array}{l}\text { (a) Trypsinized } \\
\text { cell suspension }\end{array}$ & $\begin{array}{l}\text { (b) Supernatant } \\
\text { from }(a)\end{array}$ & $\begin{array}{l}\text { (c) Washed cells } \\
\text { from }(a)\end{array}$ & $\begin{array}{l}\text { (d) Disintegrated } \\
\text { cells from }(c)\end{array}$ \\
\hline 0 & 3,400 & 1,100 & 1,100 & 2,000 \\
\hline 7 & 2,500 & 1,850 & 1,850 & 3,200 \\
\hline 27 & 616,000 & $200,000+$ & 320,000 & 500,000 \\
\hline
\end{tabular}

Before incubation and after incubation for 7 and $27 \mathrm{hr}$. groups of dishes were examined. The medium was removed, and the monolayers dispersed by the application of trypsin at $37^{\circ} \mathrm{C}$. for $15 \mathrm{~min}$. and gentle pipetting. The cells from several dishes were pooled and titrated as 'trypsinized cells'. The remainder of the suspension was centrifuged for $5 \mathrm{~min}$. at 2000 r.p.m., to deposit the cells, and the supernatant fluid titrated. The deposited cells were resuspended in Earle's saline and titrated as 'washed cells'. Some were disintegrated by ultrasonic treatment and titrated as 'washed disintegrated cells'. The results are shown in Table 5.

In the cell suspension obtained by trypsinizing monolayers about half the total virus was in the suspending fluid (supernatant). Very little virus was present in the culture medium that was removed before trypsinization and no more would have been found in the medium had incubation of the cultures continued. It is clear that trypsin caused release of virus from cells, but only about half the virus in the culture. The reason why some virus was released and some retained is not apparent. Rupture of cells during the preparation of suspensions would not appear to account for the amount of released virus that was found. 
The practical point in technique is that treatment of infected monolayers with trypsin markedly affects the distribution of virus as between cells and suspending fluid, and would thus affect experiments of this kind designed to study cell-virus relationship in culture, including those which attempt to demonstrate an eclipse phase.

In cultures incubated for $27 \mathrm{hr}$. when virus had multiplied several 100-fold, and although there was normally only a small proportion (about $0 \cdot 1-0 \cdot 7 \%$ ) of virus in the medium, trypsin caused release of much virus from cells (Table 5).

Similar experiments with EDTA have given similar results.

\section{Efficiency of ultrasonic treatment in releasing virus from cells}

The demonstration of an eclipse phase, by showing that cells which do not contain infective virus are capable of producing it when suitably incubated, requires that the technique used to establish the absence of virus would be capable of revealing a small amount if it were there. The use of ultrasonic treatment therefore requires consideration.

(a) The titre of elementary body suspension in Earle's saline plus $0.1 \%$ gelatin (standard inoculum) was increased three to fivefold by ultrasonic treatment for 1 min. (Maitland \& Postlethwaite, 1959).

(b) Recovery of virus from monolayers infected with standard inoculum was tested as follows. Inoculum was applied for $30 \mathrm{~min}$. at $21^{\circ} \mathrm{C}$. and removed. Cells were washed three times with Earle's saline and $2 \mathrm{ml}$. of Eagle's medium added. Some dishes, as control, were incubated and plaque counts made. These showed the amount of virus adsorbed from the inoculum.

Other dishes, as soon as medium was added, were treated ultrasonically for $1 \mathrm{~min}$. The contents of two to three dishes were pooled, diluted appropriately to give maximum yield (see below), and titrated by both plaque and pock counts. The plaque counts were five to twelve times greater than the controls; the pock counts were ten to fifteen times greater. Thus ultrasonic treatment increased the amount of demonstrable virus. One possible explanation is that the standard inoculum contained clumps of elementary bodies, and that some plaque-forming units which infected the cells were aggregates which became dispersed when the cells to which they were attached were disrupted ultrasonically

There was also a dilution effect when virus in disintegrated cells was titrated by plaque counts. Dilutions of $1 / 8$ or $1 / 6$ increased by two to fourfold the amount of virus detected, compared with titration of undiluted material. Further dilution did not increase the effect.

(c) When experiments similar to those in (b) were made with US inoculum the titre of virus recovered from the disintegrated monolayers, estimated by plaque counts, was only $20-60 \%$ of the controls, and $40-70 \%$ by pock counts. This loss of virus indicates an eclipse phase ( $(\mathrm{I})$ and does not furnish any information about the efficiency of recovery of ultrasonically treated inoculum adsorbed to cells.

Considering the evidence in $(a)$ and $(b)$ above it would appear that disintegration of cells by ultrasonic treatment is a satisfactory method for releasing virus from 
them. It is as efficient as any single method available. But a combination of trypsinization and ultrasonic treatment might yield more virus. The source and preparation of the virus may also come into consideration, as preliminary experiments indicate that virus in suspensions of disintegrated infected chorio-allantoic membranes does not react to ultrasonic treatment in the same way as elementary body suspensions prepared from rabbit skin (standard inoculum). It is not possible to assess the efficiency of recovering virus from infected cells in absolute terms. The finding that with standard inoculum the titre of adsorbed virus is increased as a result of ultrasonic disintegration of cells, is not in itself proof that absolutely all the virus is being recovered. However, the use of ultrasonic treatment for demonstrating an eclipse phase in monolayers infected with US inoculum appears to be justified. The low virus content of disintegrated cells, compared with whole cells, noted in $\S$ II as indicating an eclipse phase, is considered to be a valid result and not merely the outcome of an inadequate technical procedure, although there are reservations about its quantitative aspects.

\section{Effect of ultrasonic treatment on the titre of virus}

Experiments to test whether repeated ultrasonic treatment for $1 \mathrm{~min}$. periods had an adverse effect on infectivity of the virus are summarized in Table 6.

Four ml. of standard inoculum (virus diluted in Earle's saline plus $0.1 \%$ gelatin) in a $50 \mathrm{ml}$. Petri dish was treated ultrasonically for 30,90, 150 and 240 sec. The virus was titrated by plaque counts before and after each amount of treatment. The duration of treatment was cumulative but there was an interval between each stage, for titration, which avoided any harm to the virus due to possible heat accumulation.

Table 6. Effect of ultrasonic treatment on virus

$\begin{array}{ccc}\begin{array}{c}\text { Duration of } \\ \text { treatment } \\ \text { (sec.) }\end{array} & \begin{array}{c}(a) \text { Diluted in } \\ \text { Earle's saline }+\end{array} & \begin{array}{c}(b) \text { As in }(a) \text { but } \\ \text { containing } \\ \text { cell debris }\end{array} \\ \text { None } & \text { gelatin } & 70 \\ 30 & 99 & 164 \\ 60 & 165 & 161 \\ 90 & - & - \\ 120 & 147 & 169 \\ 150 & - & - \\ 180 & 142 & 161 \\ 240 & - & 163\end{array}$

A similar set of titrations was made with virus diluted in the same medium containing cell debris. This was obtained by disintegrating a monolayer in $5 \mathrm{ml}$. of medium and using it to dilute the virus.

The results show that 30 sec. treatment doubled, approximately, the titre of the virus in both media. With the saline gelatin diluent there was possibly a slight reduction with further treatment up to $150 \mathrm{sec}$. and a definite reduction at 240 sec. 
The virus in diluent containing cell debris maintained the titre teached at 30 sec. up to 240 sec.

There was thus no indication that the ultrasonic disintegration of cells infected with US inoculum would damage the virus they contained.

\section{SUMMARY}

1. When chick embryo cell monolayers were infected with ultrasonically treated elementary body suspension by a short period of adsorption some of the adsorbed virus lost infectivity in a few minutes. This was followed by a more gradual loss during incubation of the cultures. The lowest point was reached at 4-6 hr. followed by a rise in titre due to production of new virus at 7-8 hr. The quantitative assessment of these changes is discussed.

2. In such cultures, titration of intact and disintegrated cells after incubation for 4-5 hr., indicated an eclipse phase by showing an absence of infective virus in cells which ultimately produced it. The process of eclipse continued for several hours. With inoculum that had not been subjected to ultrasonic treatment it was not possible to show this by infecting HeLa cell monolayers.

3. Ultrasonically treated inoculum, compared with a similar, but untreated inoculum, had a three to fivefold higher titre. The virus units in it were more uniformly capable of infecting cells. After its adsorption to monolayers a rapid loss of some infective virus occurred within a few minutes which was not demonstrable with untreated inoculum. During incubation of monolayers infected with treated inoculum the loss of infectivity was faster, there was a more rapid production of new virus and a greater yield. The nature of the changes in the virus which were brought about by ultrasonic treatment have not been explained, but the use of such an inoculum markedly affected the results of experiments.

4. Treatment of infected monolayers with trypsin or EDTA caused the cells to shed as much as half their virus. This virus would not be released spontaneously into the medium or removed from monolayers by washing. This applied to all periods of incubation up to $24 \mathrm{hr}$. or more when marked increase of virus had occurred.

5. The disintegration of infected cells by ultrasonic treatment was efficient in releasing infective virus from them, although it was not possible to be certain all the virus in the cells was rendered detectable by this technique.

6. The effect of some technical procedures on the interpretation of results is discussed.

\section{REFERENCES}

Anderson, S. G. (1954). The growth curve of vaccinia virus on the chorioallantois. Aust. $J$. exp. Biol. med. Sci. 32, 633.

Briody, B. A. \& Stannard, C. (1951). The effect of proflavine on the growth of viruses in the chick embryo. J. Immunol. 67, 423.

Crawford, G. N. C. \& Sanders, F. K. (1952). The multiplication of vaccinia virus in tissue cultures of adult rabbit skin. Quart. J. micr. Sci. 93, 119.

ForsYTH, P. J., Cook, E. M. \& IRONS, J. V. (1954). The growth curve of vaccinia virus on the chorio-allantoic membrane of embryonated eggs. Bact. Proc. p. 89. 
Hoagland, C. L., Smadel, J. E. \& Rivers, T. M. (1940). Constituents of elementary bodies of vaccinia. I. Certain basic analyses and observations on lipid components of the virus. J. exp. Med. 71, 737.

Maitland, H. B. \& Postrlethwarte, R. (1959). Studies on vaccinia virus in HeLa cells. IX. Symp. Soc. gen. Microbiol. on Virus Growth and Variation, p. 185.

MaItLand, H. B. \& ToBIn, B. M. (1956). The growth of vaccinia virus in the chorioallantois of the developing chick embryo and the production of complement-fixing antigen and haemagglutinin. J. Hyg., Camb., 54, 102.

PostlethwaIte, R. (1959). A simple plaque method for the titration of vaccinia virus. J. gen. Microbiol. 21, vii.

Ryden, F. W. \& Randall, C. C. (1957). The growth cycle of vaccinia in HeLa cells correlated with concurrent cellular changes. Amer. J. Path. 33, 367. 